\title{
Proceeding
}

Supplementary Issue: Autumn Conferences of Sports Science. Costa Blanca Sports Science Events, 18-19 December 2020. Alicante, Spain.

\section{Social inclusion through motor activity and sport}

\author{
LUCIA MARTINIELLO1 1 , GIUSEPPE MADONNA² \\ ${ }^{1}$ Telematic University "Pegaso", Italy \\ ${ }^{2}$ Parthenope University of Naples, Italy
}

\begin{abstract}
It is now a consolidated opinion that Sport represents a universal phenomenon that has the advantage of being able to be transmitted and taught in ways that transcend cultural barriers. For this reason, sport is increasingly used in situations of social hardship to improve the inclusion and integration of those subjects who would otherwise be excluded due to their linguistic, cultural, economic or social conditions. One of the most interesting fields of application in this sense is that linked to Motor Activity projects aimed at migrants and asylum seekers, and among these projects developed by the Sports Federations of the States of the European Union, those developed through the game of football manage to generate significant involvement and results. According to the data provided by the Italian Football Federation (FIGC), the RETE! Project, developed by the Youth and School Sector and aimed at migrant minors and asylum seekers, has seen the numbers relating to participants and reception centres involved almost tripled in the 5 years. life of the project. The trend has not decreased even with the advent of the COVID-19 pandemic, a sign that Motor Activity is an important and performing tool in the process of inclusion of individuals in distress.
\end{abstract}

Keywords: Motor activity; Sport; Football; Inclusion; Migrants.

\section{Cite this article as:}

Martiniello, L., \& Madonna, G. (2021). Social inclusion through motor activity and sport. Journal of Human Sport and Exercise, 16(2proc), S590-S595. doi:https://doi.org/10.14198/jhse.2021.16.Proc2.43

Corresponding author. Telematic University "Pegaso", Italy. https://orcid.org/0000-0002-5194-6061

E-mail: lucia.martiniello@unipegaso.it

Abstract submitted to: Autumn Conferences of Sports Science. Costa Blanca Sports Science Events, 18-19 December 2020. Alicante, Spain.

JOURNAL OF HUMAN SPORT \& EXERCISE ISSN 1988-5202

(C) Faculty of Education. University of Alicante

doi:10.14198/jhse.2021.16.Proc2.43 


\section{INTRODUCTION}

Sport and physical activity are phenomena which, due to their great diffusion in the world population, are becoming increasingly important in the daily life of millions of people all over the world. Due to its great diffusion and universality, Sport can have a significant role in educational processes. According to Corsi (2011), Pedagogy must be reviewed and rethought "in the relationship with all the other sciences and not least as a science itself; a science, therefore, which is attentive to new stimuli coming from other disciplinary fields, and which at the same time be open about content and methodology".

Sport therefore has all the characteristics to represent a valid pedagogical tool capable of obtaining results even in contexts of hardship and social exclusion. This is even more true in team sports, where the cooperative aspect of the activity facilitates the processes of inclusion and highlights the positive values deriving from sporting practice. And among the positive values that sports practice has we find social participation, the search for meaning, culture, discipline and the learning of correct lifestyles: this leads those who practice sport regularly to better organize their time, to control one's character and impulses, to respect commitments and others; in short, it is about mental growth and the achievement of psychophysical wellbeing, in addition to the ability to relate to the environment.

Specifically, Sport can be an excellent driving force for social inclusion in the integration processes of migrants and asylum seekers: this article will analyse the case of a sports project implemented by the Italian Football Federation that uses football as a facilitator of the social inclusion of migrants and asylum seekers minors.

\section{THE VALUES OF SPORT}

Within the practice of any sport, the role of education can be clearly recognized: it contributes, in addition to the acquisition of technical and tactical rules, also to the formation of the personality of the sportsman. Furthermore, all the technical values typical of sports practice can be transferred as life skills in daily life, and thus contribute to building the character of practitioners.

Another characteristic of sport consists in the fact that it improves the relationship with the social and natural environment of those who practice it: this aspect can be found, for example, in the possibility of creating new friendships in the collaboration between teammates who play for the achievement of a common goal. Social relationships are also born and developed in relation to the training phase, during which, in addition to the common fun that is felt during the game, bonds are created that will last over time. Another important aspect is that often the bonds of friendship and the opportunities to socialize also derive from the meeting with the opponents of the game, as the right value that sporting practice should transmit is to see the other not as an opponent to beat. , but also as the one who offers certain stimuli to satisfy the set goals.

Sport is therefore important for the development of social relationships: however, all this occurs only when the approach to sporting activity takes place through some educational standards. Therefore, it seems necessary to put the educational question back at the centre of sport, and to do this it is essential that the idea of human capital be abandoned, aimed above all at enhancing the economic aspect of the sporting contest, offering a way of seeing sports practice. exclusively economic, enhancing the athlete in terms of costs-benefits, gains-losses, advantages-damages, initially aimed exclusively at professional-agonists and, unfortunately, subsequently also at amateurism, youth sport and sport for all. 


\section{INCLUSION THROUGH SPORT}

For all the reasons just mentioned, Sport is a tool widely used in contexts of social hardship. In fact, Sport manages to overcome obstacles of a linguistic, cultural, economic, social nature: it is a universal language that facilitates educational processes.

Sport is "the most characteristic social phenomenon of today's societies" (Garcia, Ferrando, Puig, Lagardera, 1998). According to Isidori (2019), Sport hides a learning process which, despite its complexity, can be learned by anyone, regardless of social and cultural level. This passe-partout in learning sporting activity has meant that, throughout history, playful activities have been linked to the cultures of different peoples, facilitating intercultural communication. Seen from this point of view, Sport is in effect a universal phenomenon, connected to the very nature of man and which has the great advantage of being transmitted and taught in ways that transcend cultural barriers.

Sport has characteristics of multiculturalism and transculturality which Isidori summarizes in the following points:

- Through sports, the human being reveals himself and develops communication skills that allow him to connect with others;

- Its nature, based on competition through rules, has historically allowed different groups of people and communities to confront each other's diversity through body language;

- Representing to all effects an expression of human creativity, it allows to enrich the cultural background of those who practice it, increasing their communication and relationship skills.

In an increasingly multiracial society, where different cultures, traditions and languages coexist, one cannot ignore a Sports Pedagogy that seeks to bring out the positive values of sporting activity, using it as an educational medium with all the great potential it brings with it. self. Precisely for this reason, there are many educational initiatives that, through sporting practice, aim to make social intervention in terms of integration and fight against prejudice.

\section{FOOTBALL AND INCLUSION: THE RETE PROJECT!}

About 250 million people play football at different levels; about 1.5 billion people follow it and around it revolves economic interests that can be estimated in hundreds of billions of euros. Just like real society, football also suffers from racial and integration issues. UEFA, the union of European football associations, takes this issue very seriously and has drafted an official document, the "IX Resolution: European football united against racism". The political position declared in this document, and the corresponding anti-racism measures proposed, show that there is a deep awareness on the part of this body towards the problem. The eleven-point resolution clarifies among other things that UEFA's main objective is "The promotion of sport football in a spirit of peace (...) without any form of discrimination".

Abolishing all forms of discrimination means carrying out a double operation: on the one hand, stigmatizing the manifestations of intolerance, and on the other, promoting integration processes between the parties. Sport in this sense has a strong educational power that acts on both points: its spirit not only does not foresee any kind of intolerance, but on the contrary naturally stimulates integration processes that aim to make an individual a member of society. 
Immigration is a current phenomenon, especially in Europe. The phenomenon originates from and is fuelled by extremely critical and precarious political and economic conditions in the countries of origin, sometimes on the verge of survival, so that migration represents the only hope of finding refuge and better living conditions. In countries where particularly intense migratory flows occur, new social realities are inevitably created with the related integration problems. In all cases, apart from the concrete problems of reception, intervening to overcome the barriers of "diversity", be they religious, racial or cultural, means acting in articulated and complex contexts for which it is necessary to use suitable interpretations and methodologies and specific, and in this sense football is particularly suitable for acting in contexts where new social realities appear that have integration processes as a critical point, and where normal organizational and pure subsistence approaches are not sufficient.

In recent years, migratory flows to Mediterranean countries have undergone a strong increase and consequently, in addition to a large number of adults, many minors, migrants, refugees and asylum seekers have arrived in Europe. Among the main problems to be faced for migrants, but also for the countries that welcome them, there is certainly that of Integration and Social Inclusion.

The United Nations High Commissioner for Refugees recognizes "the power and importance of Sport" (UNHCR, 2008) and stresses that Sport can play "a particularly important role" for refugees, migrants and asylum seekers.

Many Member States of the European Union, directly or through their respective Olympic Committees or National Sports Federations, carry out numerous projects of Integration and Social Inclusion through Sport, aimed at migrants, refugees and asylum seekers. The Italian Football Federation in 2015 conceived and launched in collaboration with the Ministry of the Interior and Anci the "RETE!" Project aimed at minors seeking asylum housed in the centres of the SPRAR and SIPROIMI holders of international protection and for unaccompanied foreign minors). Through sports practice, addressed and guided by specially trained instructors of the Federation, those processes of inclusion that otherwise would have hardly occurred are successfully started, increased and accelerated.

The technical-training format of the project includes three different phases, each of which is carried out under the technical and methodological supervision of the Youth and School Sector of the Italian Football Federation. In the first phase, the SPRAR and SIPROIMI centres carry out motor activities with a football orientation led by the technician assigned to them by the regional coordinators: this is the most important phase from an educational point of view, since relations are established between the group formed by the children and by their educators and federal instructors, which is why this first approach is often supervised by a sports psychologist as well. Training sessions take place 1-2 times a week, in which Italian children from local football schools are also involved. The second phase takes place through interregional concentrations during which the different teams representing the participating SPRAR and SIPROIMI centres compete in a 7-on-7 football tournament to define the teams that will access the third phase, that is the final tournament, which decrees the national tournament winning team.

The children involved have the opportunity through sport to improve their psychophysical well-being, establish relationships with other members of the community of their peers and to feel part of and not excluded from society. Football, therefore, becomes the key to convey positive and educational messages, as well as to break down barriers and stimulate integration in an increasingly multicultural society. 


\section{REFERENCES}

Agergaard, S. (2011). "Development and Appropriation of an Integration Policy for Sport: How Danish Sports Clubs Have Become Arenas for Ethnic Integration." International Journal of Sport Policy and Politics 3 (3): 341-353. https://doi.org/10.1080/19406940.2011.596158

Agazzi, A. (1975). II discorso pedagogico. Milano: Vita \& Pensiero.

Bauman, Z. (1999), La società dell'incertezza, II Mulino, Bologna.

Bradbury, S. (2011). From racial exclusions to new inclusions: Black and minority ethnic participation in football clubs in the East Midlands of England. International Review for the Sociology of Sport, 46, 23. https://doi.org/10.1177/1012690210371562

Calidoni P., Cunti A., De Anna L., De Mennato P., Gamelli I., Tarozzi M (2004), "Pedagogia ed educazione motoria" Milano, Guerini.

Corsi M., Sarracino V. (a cura di), Ricerca Pedagogica e Politiche della Formazione, Tecnodid Editor, Naples, 2011.

Cunningham, G. B., and J. S. Fink. 2006. "Diversity Issues in Sport and Leisure." Journal of Sport Management 20 (4): 455-465. https://doi.org/10.1123/jsm.20.4.455

Di Palma, D., \& Ascione, A. (2020). Training in school through motor education: an experimental pedagogical protocol. Sport Science, vol. 13 (2020) 1, p. 76-85.

Di Palma D., \& Cusano P. (2020). Didactic Innovation, Disability, Sport and Training Evaluation during Covid-19 / Italian Journal of Health Education, Sports and Inclusive Didactics - ISSN 2532-3296. https://doi.org/10.32043/gsd.v4i2.205

Di Palma, D., Ascione, A., \& Peluso Cassese, F. (2017). Gestire lo sport per uno sviluppo educa- tivo. Giornale Italiano della Ricerca Educativa - Italian Journal of Educational Research.

Farinelli, G. (2005). Pedagogia dello sport ed educazione della persona (Vol. 3). Morlacchi Editore.

Freire, P. (1970). Pedagogia degli oppressi. Arnoldo Mondadori Editore, Milano.

Garland J.R.M., (2001). Racism and antiracism in football. Palgrave Macmillan, basingstoke. https://doi.org/10.1057/9780230502529

Giusti M., (2011). Immigrazione e consumi culturali. Un'interpretazione pedagogica. Laterza, Roma.

Isidori, E., \& Fraile, A. (2008). Educazione, sport e valori. Un approccio critico-riflessivo. Roma: Aracne. Isidori, E. (2015). La Pedagogia dello Sport, Carocci Editore, Roma.

Makarova, E., and W. Herzog. 2014. "Sport as a Means of Immigrant Youth Integration: An Empirical Study of Sports, Intercultural Relations, and Immigrant Youth Integration in Switzerland." Sportwissenschaft 44 (1): 1-9. https://doi.org/10.1007/s12662-013-0321-9

Mari, G. (2007). Sport e educazione. Pedagogia e Vita, 65 (3-4), 154-175.

Mariano,A., Cambi, F., Giosi, M., Sarsini, D. (2009). Pedagogia generale. identità, percorsi, funzione. Carocci Editore, Roma.

Moliterni P. (2012). Inclusione e integrazione: lo sguardo sulla cittadinanza. In L. d'Alonzo, R. Caldin (a cura di), Questioni, sfide e prospettive della Pedagogia speciale. Napoli: Liguori.

Moliterni, P. (2013). Didattica e Scienze Motorie. Tra mediatori e integrazione. Armando Editore, Roma.

Panciroli, C., Corazza, L., Vignola, P., Marcato, E., \& Leone, D. (2018). Didattica innovativa. Soluzioni efficaci per contesti complessi. Form@ re, 18(2).

Paparella, N. (2005), La ricerca didattica nei contesti formali, non formali, informali, Monolite, Roma.

Pavone M. (2010). Dall'esclusione all'inclusione. Milano: Mondadori.

Sidentop D., (1994). Sport education: quality through positive sport experiences. Human Kinetics Publishers. 
Raiola, G., Tafuri, D. (2015).Teaching method of physical education and sports by prescriptive or heuristic learning. Journal of Human Sport and Exercise, 10(Specialissue), pp. S377-S384. https://doi.org/10.14198/ihse.2015.10.Proc1.28

Raiola, G., Lipoma, M., \& Tafuri, D. (2015). Postural control in young soccer players: differences between the cognitive approach and ecological-dynamic one. Journal of Human Sport and Exercise 10(Special Issue), pp. S385-S390. https://doi.org/10.14198/jhse.2015.10.Proc1.29

Sarracino, F., Sirignano, F.M. (a cura di) (2007). Pedagogie e Didattiche per l'Intervento Sociale. Giannini Editore, Napoli.

Sibilio, M. (2005). Lo sport come percorso educativo: attività sportive e forme intellettive. Guida Editori. Striano, M. (Ed.). (2010). Pratiche educative per l'inclusione sociale. FrancoAngeli.

Spaaij, R. (2012). Beyond the playing field: Experiences of sport, social capital, and integration among Somalis in Australia. Ethnic and Racial Studies, 35(9), 1519-1538. https://doi.org/10.1080/01419870.2011.592205

Tafuri D. et al. (2017). The role of the diversity manager for valuing diversity in Sport. Sport Science, Issue 1, 65-69.

Tafuri, D., Ascione, A., Di Palma, D., Priore, A., Maulini, C. \& Agosti, V. (2020). Didattica innovativa \& Pedagogia Speciale. Educazione, Sport, Medicina. Naples: Idelson Gnocchi Editor.

Terrone, G., Santona, A. (2012) II rischio psicopatologico in preadolescenza. Giornale italiano di psicologia, 39(3), 2012, pp.697-706.

Terrone, G., Di Sarno, V., Ferri, R., Lucarell, L. (2014) Development of personal and social autonomy in teenagers and young adults with Down Syndrome: an empirical study on self-representations in family relationships. Life Span and Disability, 17(2), 2014 pp. 223-244.

\section{@(๑) $\Theta \Theta$}

This work is licensed under a Attribution-NonCommercial-NoDerivatives 4.0 International (CC BY-NC-ND 4.0). 